Article

\title{
Constituents from the Seeds of Sophora Alopecuroides L.
}

\author{
Zi-Jian Rong ${ }^{1}$, Gao-Sheng $\mathrm{Hu}^{1}{ }^{1}$, , Shi-Yi Lin ${ }^{2}$, Ting Yan ${ }^{1}$, Na Li ${ }^{1}$, Yue Zhao ${ }^{1}$, Jing-Ming Jia ${ }^{1, *}$ \\ and An-Hua Wang ${ }^{1, *}$ \\ 1 School of Traditional Chinese Materia Medica, Shenyang Pharmaceutical University, \\ Shenyang 110016, China; rongzijianlamia@gmail.com (Z.-J.R.); hugsh_2011@163.com (G.-S.H.); \\ yantinglingxiao@163.com (T.Y.); ln4311413@163.com (N.L.); zhaoyue82@126.com (Y.Z.) \\ 2 College of pharmacy, Shenyang Pharmaceutical University, Shenyang 110016, China; lin1997615@163.com \\ * Correspondence: jiajingming@163.com (J.-M.J.); sywanganhua@163.com (A.-H.W.); \\ Tel.: +86-024-4352-0725 (J.-M.J.); +86-024-4352-0726 (A.-H.W.)
}

Received: 4 December 2019; Accepted: 15 January 2020; Published: 19 January 2020

check for updates

\begin{abstract}
Three new isoflavone glucosides, kudonol A-C (1-3), two new ester derivatives of phenylpropanoid, kudolignan A and B (4-5) and five known compounds, (-)-maackiain (6), neoliquiritin (7), methyl 4-coumarate (8), methyl ferulate (9) and (+)-wikstromol (10), were isolated from an extract of dried seeds of the traditional Chinese medicinal plant Sophora alopecuroides L. Their structures were established by NMR and HRESIMS data analyses. The monosaccharide part's configuration of isoflavone glucosides was confirmed by acid hydrolysis and analyzed by a JAsco OR-4090 chiral detector, comparing it to standard substance D-glucose. The cytotoxicity effects against HeLa, Hep3B, MCF-7 and H1299 cells were tested by CCK-8 assay.
\end{abstract}

Keywords: S. alopecuroides L.; isoflavone glucosides; structure elucidation; cytotoxicity

\section{Introduction}

Sophora alopecuroides L. is a traditional Chinese herbal plant, known as "Ku-Dou-Zi" in China, and is a perennial herbaceous plant in the Leguminosae family, which is widely distributed in the deserts of northern China, especially in the Xinjiang and Ningxia provinces as well as the Inner Mongolia Autonomous Region. The seeds of $S$. alopecuroides have a long history as a traditional Chinese medicine, utilized for the treatment of eczema, acute pharyngolaryngeal infection, sore throat, acute dysentery, and gastrointestinal hemorrhage [1].

Previous phytochemical investigations on S. alopecuroides have led to the isolation of alkaloids, flavonoids, isoflavonoids, and rotenoids [2]. Compounds isolated from the seeds of this plant have been used to treat leukemia [3], trophoblastic tumors and inflammation in traditional Chinese medicine. For example, sophocarpine was found to be effective against tumors, both in cell proliferation and metastasis in liver cancer [4].

During our present exploration for the diterpenoids of S. alopecurioides, five previously undescribed compounds were isolated and identified successfully for the first time (Figure 1). The structures of the isolated isoflavone glucosides were determined from various spectroscopic data. Finally, the inhibitory effects of some of the isolates against four cancer cell lines were evaluated in vitro using a CCK-8 bioassay. 


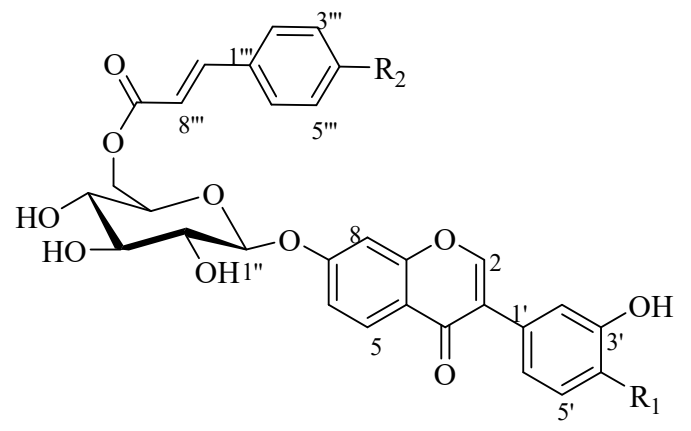

$\begin{array}{ll}\mathrm{R}_{1} & \mathrm{R}_{2}\end{array}$

$1 \mathrm{OCH}_{3} \mathrm{OH}$

$2 \mathrm{OH} \quad \mathrm{H}$<smiles>COc1cc(C(OC)C(CO)Oc2ccc(/C=C/C(=O)OC(C)F)cc2OC)ccc1O</smiles>

4 erythro

5 threo<smiles>O=C1C[C@H](c2ccc(O)cc2)Oc2cc(OC3OCC(CO)C(O)C(O)C3O)ccc21</smiles>

7<smiles>O=C(OCC1C(O)C(O)C(O)C(O)C1Oc1ccc2c(=O)c(-c3ccc(O)c(O)c3)coc2c1)c1ccccc1O</smiles>

3<smiles></smiles><smiles>COc1cc(C2c3cc(O)c(OC)cc3C[C@]3(O)C(=O)OC[C@@H]23)ccc1O</smiles>

10

Figure 1. Structures of compounds 1-10.

\section{Results and Discussion}

Compound 1 was obtained as a yellow powder and exhibited an ion peak at $m / z 591.1512([\mathrm{M}-$ $\mathrm{H}^{-}$, calcd 591.1581) in its HRESIMS data, which indicated a molecular formula of $\mathrm{C}_{31} \mathrm{H}_{28} \mathrm{O}_{12}$. The indices of hydrogen deficiency (IHDs) of compound $\mathbf{1}$ was 18 . The ${ }^{13} \mathrm{C}$ NMR data of compound $\mathbf{1}$ comprised the parent nucleus of an isoflavonoid and a monosaccharide. On the basis of the ${ }^{1} \mathrm{H}-\mathrm{NMR}$ spectroscopic data (Table 1), six aromatic proton signals at $\delta_{\mathrm{H}} 8.03(1 \mathrm{H}, \mathrm{d}, J=8.4 \mathrm{~Hz}), \delta_{\mathrm{H}} 7.20$ $(1 \mathrm{H}, \mathrm{d}, J=2.4 \mathrm{~Hz}), \delta_{\mathrm{H}} 7.14(1 \mathrm{H}, \mathrm{dd}, J=8.4,2.4 \mathrm{~Hz}), \delta_{\mathrm{H}} 6.95(1 \mathrm{H}, \mathrm{d}, J=8.4 \mathrm{~Hz}), \delta_{\mathrm{H}} 7.04(1 \mathrm{H}, \mathrm{d}$, $J=1.8 \mathrm{~Hz})$ and $\delta_{\mathrm{H}} 6.81(1 \mathrm{H}, \mathrm{dd}, J=8.4,1.8 \mathrm{~Hz})$ were observed, which were deduced to be two ABX coupled system in a sub-structure. Meanwhile, fifteen carbon signals at $\delta_{\mathrm{C}} 153.2,123.5,174.5,127.0$, 115.6, 161.2, 103.4, 156.9, 118.5, 124.4, 116.4, 146.0, 147.6, 112.0 and 119.5 in the ${ }^{13} \mathrm{C}$ NMR spectrum (Supplementary Materials) indicated the presence of structural fragments of isoflavones. A spin-spin system at $\delta_{\mathrm{H}} 5.18\left(\mathrm{H}-1^{\prime \prime}\right) / 3.36\left(\mathrm{H}-2^{\prime \prime}\right) / 3.37\left(\mathrm{H}-3^{\prime \prime}\right) / 3.27\left(\mathrm{H}-4^{\prime \prime}\right) / 3.84\left(\mathrm{H}-5^{\prime \prime}\right) / 4.45\left(\mathrm{H}-6^{\prime \prime}\right)$ was established on the basis of an ${ }^{1} \mathrm{H}^{1} \mathrm{H}$ COSY experiment, which indicated that there may be a six-carbon sugar in the structure. In its NOESY spectrum, the correlations $\delta_{\mathrm{H}} 5.18\left(\mathrm{H}-1^{\prime \prime}\right) / 3.37\left(\mathrm{H}-3^{\prime \prime}\right) / 3.84\left(\mathrm{H}-5^{\prime \prime}\right)$ and 3.36(H-2")/3.27(H-4")/4.45(H-6") established the 1"a-H, 3"a-H, 5"a-H in the six-carbon sugar ring. Six carbon signals at $\delta_{C} 99.7,73.0,76.3,70.0,73.9$ and 63.3 suggested the existence of glucose as well as an anomeric proton at $\delta_{\mathrm{H}} 5.18(\mathrm{~d}, J=7.2 \mathrm{~Hz})$. Additionally, an acid hydrolysis experiment 
performed on compound 1 afforded D-glucose, which was determined using a JAsco OR-4090 detector with D-glucose standard sample. Then, a parahydroxy cinnamic acid was deduced in the structure from the signals at $\delta_{\mathrm{H}} 7.52(2 \mathrm{H}, \mathrm{d}, J=8.4 \mathrm{~Hz})$ and $6.79(2 \mathrm{H}, \mathrm{d}, J=8.4 \mathrm{~Hz})$ and a pair of trans-ene hydrogen signals at $\delta_{\mathrm{H}} 7.56\left(1 \mathrm{H}, \mathrm{d}, J=15.6 \mathrm{~Hz}, 7^{\prime \prime \prime}-\mathrm{H}\right)$ and $6.39\left(1 \mathrm{H}, \mathrm{d}, J=15.6 \mathrm{~Hz}, 8^{\prime \prime \prime}-\mathrm{H}\right)$ in the ${ }^{1} \mathrm{H}$ NMR spectrum as well as a carbonyl carbon signal at $\delta_{\mathrm{C}} 166.3$ in the ${ }^{13} \mathrm{C}$ NMR spectrum. The analysis of the spectroscopic data indicated that compound 1 was similar to the known compound calycosin-7-O-D-glucopyranoside [5], and the difference mainly lay in the parahydroxy cinnamic acid group. The exact structure of compound 1 was established by 2D-NMR. In the HMBC spectrum, a methoxide signal at $\delta_{\mathrm{H}} 3.80$ had a long-range correlation with $\delta_{\mathrm{C}} 147.6\left(\mathrm{C}-4^{\prime}\right)$, which indicated a methoxy group connected on the $\mathrm{C}$ ring of this isoflavone. A long-range correlation was observed between $\delta_{\mathrm{H}} 5.18\left(\mathrm{H}-1^{\prime}\right)$ and $\delta_{\mathrm{C}} 161.2(\mathrm{C}-7)$, which located the D-glucose at C-7 of the isoflavone, and the anomeric proton at $\delta_{\mathrm{H}} 5.18(\mathrm{~d}, J=7.2 \mathrm{~Hz})$ also indicated the presence of a $\beta$ glycosidic bond. The parahydroxy cinnamic acid group was posited to the C- 6 of D-glucose by the HMBC correlations of $\delta_{\mathrm{H}}$ $4.45\left(\mathrm{H}-6^{\prime \prime}\right) / \delta_{\mathrm{C}} 166.3\left(\mathrm{C}-9^{\prime \prime \prime}\right)$. Based on the abovementioned data, the structure of compound 1 was elucidated as Calycosin-7-O- $\beta$-D-(6"-hydroxy cinnamate)-glucopyranoside and named as kudonol A.

Table 1. ${ }^{1} \mathrm{H}$ NMR data $(600 \mathrm{MHz})$ and ${ }^{13} \mathrm{C}$ NMR data $(150 \mathrm{MHz})$ of compounds $\mathbf{1}, 2$ and 3.

\begin{tabular}{|c|c|c|c|c|c|c|c|}
\hline \multirow{2}{*}{ Position } & \multicolumn{2}{|c|}{$1\left(\mathrm{DMSO}-d_{6}\right)$} & \multicolumn{2}{|l|}{$2\left(\mathrm{CD}_{3} \mathrm{OD}\right)$} & \multirow{2}{*}{ Position } & \multicolumn{2}{|l|}{$3\left(\mathrm{CD}_{3} \mathrm{OD}\right)$} \\
\hline & $\delta_{\mathrm{H}}(J$ in $\mathrm{Hz})$ & $\delta_{\mathrm{C}}$ & $\delta_{\mathrm{H}}(J$ in $\mathrm{Hz})$ & $\delta_{\mathrm{C}}$ & & $\delta_{\mathrm{H}}(J$ in $\mathrm{Hz})$ & $\delta_{\mathrm{C}}$ \\
\hline 2 & $8.03, \mathrm{~s}$ & 153.2 & $7.50, \mathrm{~s}$ & 154.7 & 2 & $8.04, \mathrm{~s}$ & 154.9 \\
\hline 3 & - & 123.5 & - & 124.5 & 3 & - & 124.6 \\
\hline 4 & - & 174.5 & - & 177.8 & 4 & - & 178.0 \\
\hline 5 & $8.03, \mathrm{~d}(8.4)$ & 127.0 & $8.09, \mathrm{~d}(9.0)$ & 128.2 & 5 & $8.08, \mathrm{~d}(8.4)$ & 128.3 \\
\hline 6 & $7.14, \mathrm{dd}(8.4,2.4)$ & 115.6 & $7.16, \mathrm{dd}(9.0,1.8)$ & 117.5 & 6 & $7.19, \mathrm{dd}(8.4,2.4)$ & 117.0 \\
\hline 7 & - & 161.2 & - & 163.1 & 7 & - & 163.0 \\
\hline 8 & $7.20, \mathrm{~d}(2.4)$ & 103.4 & $7.15, \mathrm{~d}(1.8)$ & 104.5 & 8 & $7.18, \mathrm{~d}(2.4)$ & 104.8 \\
\hline 9 & - & 156.9 & - & 158.9 & 9 & - & 159.0 \\
\hline 10 & - & 118.5 & - & 120.2 & 10 & - & 120.2 \\
\hline $1^{\prime}$ & - & 124.4 & - & 126.0 & $1^{\prime}$ & - & 126.2 \\
\hline $2^{\prime}$ & $7.04, \mathrm{~d}(1.8)$ & 116.4 & $6.93, \mathrm{~d}(1.8)$ & 117.4 & $2^{\prime}$ & $7.06, \mathrm{~s}$ & 117.5 \\
\hline $3^{\prime}$ & - & 146.0 & - & 146.1 & $3^{\prime}$ & - & 146.2 \\
\hline $4^{\prime}$ & - & 147.6 & - & 146.7 & $4^{\prime}$ & - & 146.8 \\
\hline $5^{\prime}$ & $6.95, \mathrm{~d}(8.4)$ & 112.0 & $6.82, \mathrm{~d}(7.8)$ & 116.2 & $5^{\prime}$ & $6.94, \mathrm{~m}$ & 116.4 \\
\hline $6^{\prime}$ & $6.81, \mathrm{dd}(8.4,1.8)$ & 119.5 & $6.67, \mathrm{dd}(7.8,1.8)$ & 121.6 & $6^{\prime}$ & $6.94, \mathrm{~m}$ & 121.7 \\
\hline $1^{\prime \prime}$ & $5.18, \mathrm{~d}(7.2)$ & 99.7 & $5.12, \mathrm{~d}(7.2)$ & 101.5 & $1^{\prime \prime}$ & $5.21, \mathrm{~d}(7.8)$ & 101.2 \\
\hline $2^{\prime \prime}$ & $3.36, \mathrm{~m}$ & 73.0 & $3.60, \mathrm{~m}$ & 74.7 & $2^{\prime \prime}$ & $3.62, \mathrm{~m}$ & 74.6 \\
\hline $3^{\prime \prime}$ & $3.37, \mathrm{~m}$ & 76.3 & $3.60, \mathrm{~m}$ & 77.8 & $3^{\prime \prime}$ & $3.62, \mathrm{~m}$ & 77.8 \\
\hline $4^{\prime \prime}$ & $3.27, \mathrm{~m}$ & 70.0 & $3.47, \mathrm{~m}$ & 72.0 & $4^{\prime \prime}$ & $3.51, \mathrm{~m}$ & 72.0 \\
\hline $5^{\prime \prime}$ & $3.84, \mathrm{~m}$ & 73.9 & $3.92, \mathrm{~m}$ & 75.7 & $5^{\prime \prime}$ & $4.00, \mathrm{~m}$ & 75.5 \\
\hline $6 "$ & $\begin{array}{c}4.45, \mathrm{dd}(12.0,1.8) \\
4.21, \mathrm{~m}\end{array}$ & 63.3 & $\begin{array}{c}4.64, \mathrm{dd}(12.0,1.8) \\
4.45, \mathrm{~m}\end{array}$ & 64.9 & $6^{\prime \prime}$ & $\begin{array}{c}4.81, \mathrm{dd}(12.0,1.8) \\
4.56, \mathrm{~m}\end{array}$ & 65.6 \\
\hline $1^{\prime \prime \prime}$ & - & 125.0 & - & 135.7 & $1^{\prime \prime \prime}$ & - & 113.5 \\
\hline $2^{\prime \prime \prime} / 6^{\prime \prime \prime}$ & $7.52, \mathrm{~d}(8.4)$ & 130.3 & $7.55, \mathrm{~d}(8.4)$ & 129.2 & $2^{\prime \prime \prime}$ & - & 162.8 \\
\hline $3^{\prime \prime \prime} / 5^{\prime \prime \prime}$ & $6.79, \mathrm{~d}(8.4)$ & 115.8 & $7.35, \mathrm{~d}(8.4)$ & 130.2 & $3^{\prime \prime \prime}$ & $6.94, \mathrm{~m}$ & 118.4 \\
\hline $4^{\prime \prime \prime}$ & - & 159.9 & $7.34, \mathrm{~m}$ & 131.7 & $4^{\prime \prime \prime}$ & $7.52, \mathrm{~m}$ & 137.0 \\
\hline $7^{\prime \prime \prime}$ & $7.56, \mathrm{~d}(15.6)$ & 144.9 & $7.70, \mathrm{~d}(15.6)$ & 146.6 & $5^{\prime \prime \prime}$ & $6.94, \mathrm{~m}$ & 120.4 \\
\hline $8^{\prime \prime \prime}$ & 6.39, d (15.6) & 113.9 & $6.56, d(15.6)$ & 118.7 & $6^{\prime \prime \prime}$ & 7.95, dd $(7.8,1.8)$ & 131.2 \\
\hline $9^{\prime \prime \prime}$ & - & 166.3 & - & 168.1 & $7^{\prime \prime \prime}$ & - & 171.0 \\
\hline$-\mathrm{OCH}_{3}$ & $3.80, \mathrm{~s}$ & 55.6 & - & - & - & - & - \\
\hline
\end{tabular}

Compound 2, a yellow powder, gave the molecular formula $\mathrm{C}_{30} \mathrm{H}_{26} \mathrm{O}_{11}$ through HRESIMS of its quasi-molecular ion peak at $m / z 561.1405\left([\mathrm{M}-\mathrm{H}]^{-}\right.$, calcd 561.1475). The spectroscopic data indicated that compound 2 was similar to compound 1, except for an absence of a methoxy group and an extra aromatic proton signal. Based on a long-range correlation of $\mathrm{H}-1^{\prime \prime}\left(\delta_{\mathrm{H}} 5.12, J=7.2 \mathrm{~Hz}\right) / \mathrm{C}-7\left(\delta_{\mathrm{C}}\right.$ 163.1) observed in the HMBC data, the glucose moiety was located at $C-7$ of the isoflavone fragments. Meanwhile, a structural fragment of cinnamic acid was evidenced by signals at $\delta_{\mathrm{H}} 7.55(1 \mathrm{H}, \mathrm{d}$, $J=8.4 \mathrm{~Hz}), 7.35(1 \mathrm{H}, \mathrm{d}, J=8.4 \mathrm{~Hz})$ and $7.34(1 \mathrm{H}, \mathrm{m})$ in the ${ }^{1} \mathrm{H}$ NMR spectrum and a carbonyl carbon 
signal at $\delta_{\mathrm{C}} 168.1$ in the ${ }^{13} \mathrm{C}$ NMR spectrum. Additionally, a long-range correlation was observed from $\delta_{\mathrm{H}} 4.46\left(\mathrm{H}-6^{\prime \prime}\right)$ to $\delta_{\mathrm{C}} 168.1$ (C-9"'), which located the cinnamic acid at C-6 of the glucose. Compared with compound $\mathbf{1}$, the structure of compound $\mathbf{2}$ has a hydroxy group instead of the methoxy group present in the $\mathrm{B}$ ring of the isoflavone parent nucleus. Consequently, the structure of compound $\mathbf{2}$ was elucidated to be $7,3^{\prime}, 4^{\prime}$-trihydroxyisoflavone-7-O- $\beta$-D-(6"-cinnamic acid)-glucopyranoside and named as kudonol B.

Compound 3 had the molecular formula $\mathrm{C}_{28} \mathrm{H}_{24} \mathrm{O}_{12}$ according to the HRESIMS data from its quasi-molecular ion peak at $m / z 553.1336\left([\mathrm{M}+\mathrm{H}]^{+}\right.$, calcd 553.1268). On the basis of spectroscopic data, compound 3 was deduced to be an isoflavone glycoside, which was similar to compound 1; the main difference was that cinnamic acid was replaced by a 2-hydroxy benzoyl group, as well as a hydroxy group instead of the methoxy at $C-4^{\prime}$. The hydrolysis experiment on compound 3 gave a monosaccharide, which was identified to be of the D-glucopyranosyl group by the corresponding standard substances. Through the analysis of spectral data, a salicylic acid group was deduced from $\delta_{C}$ 113.5, 162.8, 118.4, 137.0, 120.4, 131.2 and 171.0 in the ${ }^{13} \mathrm{C}$ NMR spectrum, and that was attached to the C-6 position of the glucose with the carboxyl of itself, which was indicated from the long-correlation between $\delta_{\mathrm{H}} 4.81\left(\mathrm{H}-6^{\prime \prime}\right)$ and $\delta_{\mathrm{C}} 171.0\left(\mathrm{C}-7^{\prime \prime \prime}\right)$. Consequently, the structure of compound 3 was elucidated to be $7,3^{\prime}, 4^{\prime}$-trihydroxyisoflavone-7-O- $\beta$-D-( $6^{\prime \prime}$-salicylic acid)-glucopyranoside and was named as kudonol C.

Compound 4 was obtained as a pale yellow powder and exhibited an ion peak at $m / z 455.1673$ ([M $+\mathrm{Na}]^{+}$, calcd 455.1682) in its HRESIMS data, which indicated a molecular formula of $\mathrm{C}_{23} \mathrm{H}_{28} \mathrm{O}_{8}$. The ${ }^{1} \mathrm{H}$ NMR spectrum of compound 4 (see Table 2) showed six aromatic proton signals at $\delta_{\mathrm{H}} 7.16(1 \mathrm{H}, \mathrm{d}$, $J=1.8 \mathrm{~Hz}, \mathrm{H}-2), 6.93(1 \mathrm{H}, \mathrm{d}, J=8.4 \mathrm{~Hz}, \mathrm{H}-5), 7.08(1 \mathrm{H}, \mathrm{dd}, J=8.4,1.8 \mathrm{~Hz}, \mathrm{H}-6), 6.98(1 \mathrm{H}, \mathrm{d}, J=1.8 \mathrm{~Hz}$, $\left.\mathrm{H}-2^{\prime}\right), 6.76\left(1 \mathrm{H}, \mathrm{d}, J=7.8 \mathrm{~Hz}, \mathrm{H}-5^{\prime}\right)$ and $6.84\left(1 \mathrm{H}, \mathrm{dd}, J=7.8,1.8 \mathrm{~Hz}, \mathrm{H}-6^{\prime}\right)$, revealing the presence of two ABX system aromatic rings. Two olefin proton signals were observed at $\delta_{\mathrm{H}} 7.16(1 \mathrm{H}, \mathrm{d}, J=16.2 \mathrm{~Hz}, \mathrm{H}-7)$ and $6.40(1 \mathrm{H}, \mathrm{d}, J=16.2 \mathrm{~Hz}, \mathrm{H}-8)$ in the lower field region in the ${ }^{1} \mathrm{H}$ NMR spectrum. Two oxymethine protons at $\delta_{\mathrm{H}} 4.40\left(1 \mathrm{H}, \mathrm{d}, J=6.6 \mathrm{~Hz}, \mathrm{H}-7^{\prime}\right)$ and $4.54\left(1 \mathrm{H}, \mathrm{m}, \mathrm{H}-8^{\prime}\right)$, and two oxymethylene protons at $\delta_{\mathrm{H}}$ $3.86\left(2 \mathrm{H}, \mathrm{d}, J=4.8 \mathrm{~Hz}, \mathrm{H}-9^{\prime}\right)$, established the presence of a 1,2,3-propanetriol moiety. Additionally, one ethoxy group at $\delta_{\mathrm{H}} 4.26\left(2 \mathrm{H}, \mathrm{q}, J=7.2 \mathrm{~Hz}, \mathrm{H}-1^{\prime \prime}\right)$ and $1.35\left(3 \mathrm{H}, \mathrm{t}, J=7.2 \mathrm{~Hz}, \mathrm{H}-2^{\prime \prime}\right)$ and three methoxy groups at $\delta_{\mathrm{H}} 3.83\left(\mathrm{~s}, 3, \mathrm{OCH}_{3}\right), 3.82\left(\mathrm{~s}, 3, \mathrm{OCH}_{3}\right)$ and $3.26\left(\mathrm{~s}, 3, \mathrm{OCH}_{3}\right)$ were observed in the ${ }^{1} \mathrm{H} \mathrm{NMR}$ spectrum. The ${ }^{13} \mathrm{C}$ NMR spectrum of compound 4 (see Table 2 ) showed 23 carbon signals. Aside from the carbon signal of the ethoxy unit and the three methoxy groups, the remaining 18 carbon signals included a carbonyl signal at $\delta_{\mathrm{C}} 169.1$ (C-9), double ring olefin carbon signals at $\delta_{\mathrm{C}} 116.8(\mathrm{C}-8)$ and 146.1 (C-9), 12 aromatic carbons, and three aliphatic carbons at $83.7\left(\mathrm{C}-7^{\prime}\right), 84.7\left(\mathrm{C}-8^{\prime}\right)$ and $62.3\left(\mathrm{C}-9^{\prime}\right)$. The HMBC correlations of H-7 at $\delta_{\mathrm{H}} 7.61$ with C-2, of $\mathrm{H}-8$ at $\delta_{\mathrm{H}} 6.40$ with C-6 and C-9, and of $\mathrm{H}-7^{\prime}$ at $\delta_{\mathrm{H}} 4.40$ with $\mathrm{C}-2^{\prime}, \mathrm{C}-5^{\prime}, \mathrm{C}-6^{\prime}$ and $\mathrm{C}-8^{\prime}$ confirmed the presence of two phenyl propanoid units. In the HMBC spectrum, the correlation of $\mathrm{H}-8^{\prime}$ at $\delta_{\mathrm{H}} 4.54$ with $\mathrm{C}-4$ at $\delta_{\mathrm{C}} 151.8$ suggested that compound 4 was an $8^{\prime}-\mathrm{O}-4$ system neolignan. The methoxy group was determined to be at C-3, C-3' and C-7', based on the HMBC correlation of the methoxy groups at $\delta_{\mathrm{H}} 3.83$ with $\mathrm{C}-3$ at $\delta_{\mathrm{C}} 151.8$ and at $\delta_{\mathrm{H}} 3.82$, with $C-3^{\prime}$ at $\delta_{\mathrm{C}} 148.9$ and $\delta_{\mathrm{H}} 3.26$, and with $\mathrm{C}-7^{\prime}$ at $\delta_{\mathrm{C}}$ 83.7. Compound 5 , a pale yellow powder, gave the same molecular formula through HRESIMS, the spectroscopic data indicated that compound 5 was similar to compound 4, except for the difference of their absolute configuration. Regarding the configurations of compounds 4 and 5, the difference in chemical shifts of both $\mathrm{H}_{-} \mathbf{9}^{\prime}$ protons is the parameter that must be used to establish the relative configuration around the chiral centers $\mathrm{H}-\mathrm{7}^{\prime}$ and $\mathrm{H}-8^{\prime}[6,7]$, in compound 4 both $\mathrm{H}-9^{\prime}$ protons seem to be isochronous $\left(\delta_{\mathrm{H}} 3.86\right)$, whereas there is a difference of $0.20 \mathrm{ppm}\left(\delta_{\mathrm{H}} 3.71\right.$ and 3.51) in the chemical shift of these protons in compound 5 , thus confirming that $\mathbf{4}$ and $\mathbf{5}$ have erythro and threo relative configurations, respectively, namely these are an erythro/threo pair. Thus, the structure of compound 4 was determined to be erythro- $4^{\prime}, 9^{\prime}$-dihydroxy$3,3^{\prime}, 7^{\prime}$-trimethoxy-9-ethyoxyl-8-4-oxyneolignan and was named as kudolignan A (4), and 5 was determined to be threo-4', $9^{\prime}$-dihydroxy-3,3', $7^{\prime}$-trimethoxy-9-ethyoxyl-8-4-oxyneolignan named as kudolignan B (5). 
Table 2. ${ }^{1} \mathrm{H}$ NMR data $(600 \mathrm{MHz})$ and ${ }^{13} \mathrm{C}$ NMR data $(150 \mathrm{MHz})$ of compounds $4-5\left(\mathrm{CD}_{3} \mathrm{OD}\right)$.

\begin{tabular}{|c|c|c|c|c|}
\hline \multirow{2}{*}{ Position } & \multicolumn{2}{|l|}{4} & \multicolumn{2}{|l|}{5} \\
\hline & $\delta_{\mathrm{H}}(J$ in $\mathrm{Hz})$ & $\delta_{\mathrm{C}}$ & $\delta_{\mathrm{H}}(J$ in $\mathrm{Hz})$ & $\delta_{\mathrm{C}}$ \\
\hline 1 & - & 129.5 & - & 129.4 \\
\hline 2 & $7.16, \mathrm{~d}(1.8)$ & 112.3 & $7.24, \mathrm{~d}(2.4)$ & 112.3 \\
\hline 3 & - & 151.8 & - & 152.4 \\
\hline 4 & - & 151.7 & - & 151.7 \\
\hline 5 & $6.93, \mathrm{~d}(8.4)$ & 117.4 & $7.04, \mathrm{~d}(8.4)$ & 117.2 \\
\hline 6 & $7.08, \mathrm{dd}(8.4,1.8)$ & 123.3 & $7.13, \mathrm{dd}(8.4,2.4)$ & 123.5 \\
\hline 7 & $7.61, \mathrm{~d}(16.2)$ & 146.1 & $7.64, \mathrm{~d}(16.2)$ & 146.1 \\
\hline 8 & $6.40, \mathrm{~d}(16.2)$ & 116.8 & $6.42, \mathrm{~d}(16.2)$ & 116.8 \\
\hline 9 & - & 169.1 & - & 169.1 \\
\hline $1^{\prime}$ & - & 130.6 & - & 130.8 \\
\hline $2^{\prime}$ & $6.98, \mathrm{~d}(1.8)$ & 112.5 & $7.00, \mathrm{~d}(1.8)$ & 112.1 \\
\hline $3^{\prime}$ & - & 148.9 & - & 149.1 \\
\hline $4^{\prime}$ & - & 147.5 & - & 147.6 \\
\hline $5^{\prime}$ & $6.76, \mathrm{~d}(7.8)$ & 115.6 & $6.81, \mathrm{~d}(7.8)$ & 116.0 \\
\hline $6^{\prime}$ & $6.84, \mathrm{dd}(7.8,1.8)$ & 122.3 & $6.85, \mathrm{dd}(7.8,1.8)$ & 121.6 \\
\hline $7^{\prime}$ & $4.40, \mathrm{~d}(6.6)$ & 83.7 & $4.47, \mathrm{~d}(6.0)$ & 84.2 \\
\hline $8^{\prime}$ & $4.54, \mathrm{~m}$ & 84.7 & $4.50, \mathrm{~m}$ & 85.1 \\
\hline $9^{\prime}$ & $3.86, \mathrm{~d}(4.8)$ & 62.3 & 3.71, dd $(12.0,4.2) 3.51, \mathrm{q}(6.0)$ & 62.2 \\
\hline $1^{\prime \prime}$ & $4.26, q(7.2)$ & 61.5 & $4.26, \mathrm{q}(7.2)$ & 61.5 \\
\hline $2^{\prime \prime}$ & $1.35, \mathrm{t}(7.2)$ & 14.6 & $1.35, \mathrm{t}(7.2)$ & 14.6 \\
\hline $3-\mathrm{OCH}_{3}$ & $3.83, \mathrm{~s}$ & 56.5 & $3.92, \mathrm{~s}$ & 56.6 \\
\hline $3^{\prime}-\mathrm{OCH}_{3}$ & $3.82, \mathrm{~s}$ & 56.3 & $3.85, \mathrm{~s}$ & 56.3 \\
\hline $7^{\prime}-\mathrm{OCH}_{3}$ & $3.26, \mathrm{~s}$ & 57.0 & $3.26, \mathrm{~s}$ & 57.2 \\
\hline
\end{tabular}

The other known compounds were identified as (-)-maackiain (6) [8], neoliquiritin (7) [9], methyl 4-coumarate (8) [10], methyl ferulate (9) [11] and (+)-Wikstromol (10) [12] from the comparison of their NMR data with that reported in the literature.

Compounds 1-6 were tested for their cytotoxicity against four human cancer cell lines (HeLa, Hep3B, MCF-7 and H1299) and one normal human liver cell line (LO2) (see Table 3). Experimental results show that all of the compounds showed no cytotoxicity to the LO2 cell line, compound 2 showed moderate inhibition of cell proliferation against several cancer cell lines, and compound $\mathbf{1}$ showed moderate inhibition of cell proliferation against Hep3B cells. On the basis of structural analysis, the activity of inhibiting the compounds' cytotoxicity against tumor cells was probably due to the trans-cinnamic acid moiety.

Table 3. Inhibition effects on the growth of tumor cells in vitro $\left(\mathrm{IC}_{50}, \mu \mathrm{M}\right)$.

\begin{tabular}{cccccc}
\hline \multirow{2}{*}{ Compounds } & \multicolumn{5}{c}{ IC $_{\mathbf{5 0}} \pm$ SEM $(\boldsymbol{\mu M})$} \\
\cline { 2 - 6 } & HeLa & Hep3B & MCF-7 & H1299 & LO2 \\
\hline $\mathbf{1}$ & $118.237 \pm 15.524$ & $>150$ & $>150$ & $>150$ & $>150$ \\
$\mathbf{2}$ & $68.033 \pm 8.321$ & $85.366 \pm 27.313$ & $>150$ & $77.366 \pm 17.309$ & $>150$ \\
$\mathbf{3}$ & $>150$ & $>150$ & $>150$ & $>150$ & $>150$ \\
$\mathbf{4}$ & $>150$ & $>150$ & $>150$ & $>150$ & $>150$ \\
$\mathbf{5}$ & $>150$ & $>150$ & $>150$ & $>150$ & $>150$ \\
$\mathbf{6}$ & $97.590 \pm 20.504$ & $124.909 \pm 35.021$ & $99.742 \pm 17.001$ & $68.376 \pm 11.528$ & $>150$ \\
$\mathbf{5 - F u}$ & $15.990 \pm 0.121$ & $32.223 \pm 3.257$ & $14.450 \pm 2.193$ & $24.450 \pm 6.153$ & $>150$ \\
\hline
\end{tabular}

\section{Experimental Section}

\subsection{General Experimental Procedures}

NMR spectra were run in DMSO- $d_{6}$ and $\mathrm{CD}_{3} \mathrm{OD}$ on a Varian Mercury NMR spectrometer. Analytical HPLC data were collected on an Agilent 1260 infinity II instrument (Thermo Scientific 
dionex). The UV spectra were measured by an Agilent 1260 infinity II UV-vis spectrophotometer in methanol. Preparative HPLC was performed by a Saipuruisi MH-LC 52 instrument with an Elite UV2300 detector and an YMC C18 column $(250 \times 20 \mathrm{~mm}, 5 \mu \mathrm{m})$. The HRESIMS data were obtained using an Agilent 1290 series 6540 UHD accurate mass Q-TOF mass spectrometer using direction injection. The sugar configurations were determined by a JAsco OR-4090 chiral detector. Column chromatographic separations were carried out on silica gel H-60 (Qingdao Marine Chemical Group Corporation, Qingdao, China), Polyamide (Shanghai Yiyan biology technology Co. Ltd., Zhengzhou, China) and Sephadex LH-20 (Shanghai Yi-He biological technology Co. Ltd., Shanghai, China). The Acetonitrile and Methanol used were of chromatographic grade, and were purchased from Fisher in America. All other solvents used of chemical grade (Da-Mao Chemical Co. Ltd., Tianjin, China).

\subsection{Plant Materials}

The dry seeds of S. alopecuroides L. were collected from Alxa League in Inner Mongolia Autonomous Region and identified by Prof. Liu Yong, Jiang-Xi University of Chinese Medicine. The specimens were deposited in the specimen room of traditional Chinese Medicine in Shenyang Pharmaceutical University (SPU-2014-0714-06).

\subsection{Extraction and Isolation}

The dry seeds of S. alopecuroides L. (50 kg) were extracted by $70 \%$ ethanol aqueous solution, refluxed $(1.5 \mathrm{~h} \times 3)$ and adjusted to a $\mathrm{pH}$ of 2 by $1 \% \mathrm{HCl}$, and then partitioned with EtOAc. The EtOAc portion (336 g) was partitioned by polyamide chromatography $\left(\mathrm{EtOH} / \mathrm{H}_{2} \mathrm{O}\right)$ and yielded four fractions (100\% water, 30\% EtOH, 60\% EtOH, 90\% EtOH). Afterwards, the fraction of $60 \% \mathrm{EtOH}(51 \mathrm{~g})$ was dealt with by a silica gel column by elution with $\mathrm{CH}_{2} \mathrm{Cl}_{2}: \mathrm{CH}_{3} \mathrm{OH}$ (100:1-0:100) in sequence to give fractions 1-19. Sub-fraction 12 was separated by medium pressure ODS CC (0.03\% TFA, 45-100\% $\mathrm{CH}_{3} \mathrm{OH}$ aqueous) to obtain 22 fractions, $1^{\prime}-22^{\prime}$. Fraction $6^{\prime}$ was purified by preparative HPLC with $\mathrm{CH}_{3} \mathrm{CN}-\mathrm{H}_{2} \mathrm{O}\left(30 \%, 0.03 \%\right.$ TFA) to get compound 1 (12.7 $\left.\mathrm{mg}, \mathrm{t}_{\mathrm{R}}=16.06 \mathrm{~min}\right)$, compound 2 (18.9 $\mathrm{mg}$, $\left.\mathrm{t}_{\mathrm{R}}=21.50 \mathrm{~min}\right)$ and compound $3\left(20.4 \mathrm{mg}, \mathrm{t}_{\mathrm{R}}=17.45 \mathrm{~min}\right)$. Fraction $2^{\prime}$ was purified by preparative $\mathrm{HPLC}$ with $\mathrm{CH}_{3} \mathrm{CN}-\mathrm{H}_{2} \mathrm{O}(15 \%, 0.03 \% \mathrm{TFA})$ to get compound 7 (2.2 $\left.\mathrm{mg}, \mathrm{t}_{\mathrm{R}}=16.06 \mathrm{~min}\right)$. Sub-fraction 4 was separated by Sephadex $\mathrm{LH}-20\left(90 \% \mathrm{CH}_{3} \mathrm{OH}\right.$ aqueous) to obtained 16 fractions 1"-16". Fraction 9" was purified by preparative $\mathrm{HPLC}$ with $\mathrm{CH}_{3} \mathrm{OH}-\mathrm{H}_{2} \mathrm{O}(60 \%, 0.03 \%$ TFA) to get compound 4 (3.1 $\mathrm{mg}$, $\left.\mathrm{t}_{\mathrm{R}}=21.44 \mathrm{~min}\right)$ and compound $5\left(3.2 \mathrm{mg}, \mathrm{t}_{\mathrm{R}}=23.01 \mathrm{~min}\right)$. Sub-fraction 3 was separated by medium pressure ODS CC (0.03\% TFA, 10-100\% $\mathrm{CH}_{3} \mathrm{OH}$ aqueous) to obtain 14 fractions 1"'-14"'. Fraction 10"' was purified by preparative $\mathrm{HPLC}$ with $\mathrm{CH}_{3} \mathrm{OH}-\mathrm{H}_{2} \mathrm{O}(40 \%, 0.03 \%$ TFA) to get compound 8 (2.1 $\mathrm{mg}$, $\left.\mathrm{t}_{\mathrm{R}}=40.02 \mathrm{~min}\right)$ and compound $9\left(2.5 \mathrm{mg}, \mathrm{t}_{\mathrm{R}}=42.33 \mathrm{~min}\right)$. Fraction $11^{\prime \prime \prime}$ was purified by preparative $\mathrm{HPLC}$ with $\mathrm{CH}_{3} \mathrm{OH}-\mathrm{H}_{2} \mathrm{O}\left(50 \%, 0.03 \%\right.$ TFA) to get compound 6 (42.4 mg, $\left.\mathrm{t}_{\mathrm{R}}=24.21 \mathrm{~min}\right)$. Fraction 9"' was purified by preparative $\mathrm{HPLC}$ with $\mathrm{CH}_{3} \mathrm{OH}-\mathrm{H}_{2} \mathrm{O} 35 \%, 0.03 \%$ TFA) to get compound 10 (2.3 mg, $\left.\mathrm{t}_{\mathrm{R}}=39.15 \mathrm{~min}\right)$.

\subsubsection{Kurosol A (1)}

A yellow powder; $[\alpha]_{\mathrm{D}}{ }^{20}-39.12(\mathrm{c} 0.3, \mathrm{MeOH})$; UV $\lambda_{\max } 196,264$ and $292 ;{ }^{1} \mathrm{H}$ NMR (DMSO- $d_{6}$, $600 \mathrm{MHz})$ and ${ }^{13} \mathrm{C}$ NMR (DMSO- $\left.d_{6}, 150 \mathrm{MHz}\right)$, see Table 1 ; HRESIMS m/z $591.1512\left(\left[\mathrm{M}-\mathrm{H}^{-}{ }^{-}\right.\right.$, calcd 591.1581).

\subsubsection{Kurosol B (2)}

A yellow powder; $[\alpha]_{\mathrm{D}}{ }^{20}-71.97(\mathrm{c} 0.8, \mathrm{MeOH}) ; \mathrm{UV} \lambda_{\max } 200,218$ and $264 ;{ }^{1} \mathrm{H}$ NMR $\left(\mathrm{CD}_{3} \mathrm{OD}\right.$, $600 \mathrm{MHz})$ and ${ }^{13} \mathrm{C}$ NMR $\left(\mathrm{CD}_{3} \mathrm{OD}, 150 \mathrm{MHz}\right)$, see Table 1 ; HRESIMS m/z 561.1405 ([M - H $]^{-}$, calcd 561.1475). 


\subsubsection{Kurosol C (3)}

A yellow powder; $[\alpha]_{D}{ }^{20}-28.00(\mathrm{c} 0.8, \mathrm{MeOH}) ; \mathrm{UV} \lambda_{\max } 204$ and $290 ;{ }^{1} \mathrm{H}$ NMR $\left(\mathrm{CD}_{3} \mathrm{OD}, 600 \mathrm{MHz}\right)$ and ${ }^{13} \mathrm{C}$ NMR $\left(\mathrm{CD}_{3} \mathrm{OD}, 150 \mathrm{MHz}\right)$, see Table 1; HRESIMS $\mathrm{m} / z 553.1336\left([\mathrm{M}+\mathrm{H}]^{+}\right.$, calcd 553.1268).

\subsubsection{Kudolignan A (4)}

A pale yellow powder; $[\alpha]_{\mathrm{D}}{ }^{20}-14.60(\mathrm{c} 0.2, \mathrm{MeOH}) ; \mathrm{UV} \lambda_{\max } 198,230$ and $324 ;{ }^{1} \mathrm{H} \mathrm{NMR}\left(\mathrm{CD}_{3} \mathrm{OD}\right.$, $600 \mathrm{MHz})$ and ${ }^{13} \mathrm{C}$ NMR $\left(\mathrm{CD}_{3} \mathrm{OD}, 150 \mathrm{MHz}\right)$, see Table 2; HRESIMS $\mathrm{m} / z 455.1673\left([\mathrm{M}+\mathrm{Na}]^{+}\right.$, calcd 455.1682).

\subsubsection{Kudolignan B (5)}

A pale yellow powder; $[\alpha]_{\mathrm{D}}{ }^{20}-21.53(\mathrm{c} 0.1, \mathrm{MeOH}) ; \mathrm{UV} \lambda_{\max } 200,230$ and $322 ;{ }^{1} \mathrm{H}$ NMR $\left(\mathrm{CD}_{3} \mathrm{OD}\right.$, $600 \mathrm{MHz})$ and ${ }^{13} \mathrm{C}$ NMR $\left(\mathrm{CD}_{3} \mathrm{OD}, 150 \mathrm{MHz}\right)$, see Table 2; HRESIMS $\mathrm{m} / z$ 455.1676 ([M + Na ${ }^{+}$, calcd 455.1682).

\subsection{Acid Hydrolysis}

Five milligrams of powder of compounds $\mathbf{1}, 2$ and $\mathbf{3}$ were dissolved in $\mathrm{CH}_{3} \mathrm{OH}$ (the least amount) and participated in an acid hydrolysis reaction with $2 \mathrm{M}$ of $\mathrm{HCl}$ in a $90{ }^{\circ} \mathrm{C}$ water bath over 5 hours [13]. The reaction mixture was cooled to room temperature and extracted by EtOAc three times. Then, the water layer was evaporated in vacuo by a rotatory evaporator to remove the remaining EtOAc. The residue was dissolved in water again and next analyzed by HPLC coupled to a JAsco OR-4090 chiral detector, comparing it to standard substance glucose (chromatography column: Shodex Asahipak NH2P-504E, $\left.\mathrm{CH}_{3} \mathrm{CN}: \mathrm{H}_{2} \mathrm{O}(3: 1), 0.8 \mathrm{~mL} / \mathrm{min}\right)$.

\subsection{Cytotoxicity Assay}

Compounds 1-6 were tested for their cytotoxicity against the MCF-7, Hela, H1299 and Hep-3B cell lines by means of the CCK-8 method as described in the literature [14,15]. 5-fluorouracil was used as a positive control.

\section{Conclusions}

Three new isoflavone glucosides, termed kudonol A-C (1-3), two new ester derivatives of phenylpropanoid, kudolignan A and B (4-5) together with five known compounds (6-10), were isolated from the seeds of $S$. alopecuroides. The absolute configurations of compounds $\mathbf{4}-\mathbf{5}$ were determined by the extensive analysis of spectroscopic data and quantum chemical ECD calculations. Unfortunately, the cytotoxicity of compounds $\mathbf{2}$ and $\mathbf{6}$ that were evaluated against the tumor cell lines showed only weak activity. In addition, further biological assays of these compounds and the structural diversity of $S$. alopecuroides are worth exploring in future research.

Supplementary Materials: The following are available online. HREIMS, ${ }^{1} \mathrm{H}-\mathrm{NMR},{ }^{13} \mathrm{C}-\mathrm{NMR}, \mathrm{HMBC}$, and HSQC spectra of new compounds are available as supporting information.

Author Contributions: Z.-J.R., G.-S.H. and S.-Y.L. performed the experiments; T.Y., N.L. and Y.Z. contributed to manuscript preparation; J.-M.J. dealt with the structure analysis of compounds; A.-H.W. designed the whole experiments, analyzed the data and wrote the paper. All authors have read and agreed to the published version of the manuscript.

Funding: This research was funded by the National Key R\&D Program of China (2017YFC1701200) and the National Natural Science Foundation of China (No. 81374061, 81903789).

Acknowledgments: We appreciate the help of Ma Guang-Rui at the forestry bureau of Alxa league.

Conflicts of Interest: The authors declare no conflict of interest. 


\section{References}

1. Gao, H.-Y.; Li, G.-Y.; Wang, J.-H. A New Alkaloid from the Seeds of Sophora alopecuroides L. Helvetica Chim. Acta 2012, 95, 1108-1113. [CrossRef]

2. Raksat, A.; Maneerat, W.; Andersen, R.J.; Pyne, S.G.; Laphookhieo, S. Antibacterial Prenylated Isoflavonoids from the Stems of Millettia extensa. J. Nat. Prod. 2018, 81, 1835-1840. [CrossRef] [PubMed]

3. Huang, Y.-X.; Wang, G.; Zhu, J.-S.; Zhang, R.; Zhang, J. Traditional uses, phytochemistry, and pharmacological properties of Sophora alopecuroides L. Eur. J. Inflamm. 2016, 14, 128-132. [CrossRef]

4. Zhang, P.-P.; Wang, P.-Q.; Qiao, C.-P.; Zhang, Q.; Zhang, J.-P.; Chen, F.; Zhang, X.; Xie, W.-F.; Yuan, Z.-L.; Li, Z.-S.; et al. Differentiation therapy of hepatocellular carcinoma by inhibiting the activity of AKT/GSK-3 $\beta / \beta$-catenin axis and TGF- $\beta$ induced EMT with sophocarpine. Cancer Lett. 2016, 376, 95-103. [CrossRef] [PubMed]

5. Du, X.G.; Bai, Y.J.; Liang, H.; Wang, Z.Y.; Zhao, Y.Y.; Zhang, Q.Y.; Huang, L.Q. Solvent effect in 1H NMR spectra of 3"-hydroxy-4"-methoxy isoflavonoids from Astragalus membranaceus var. Mongholicus. Magn. Reson. Chem. 2006, 44, 708-712. [CrossRef] [PubMed]

6. Xue, C.-B.; Chai, D.-W.; Jin, X.-J.; Bi, Y.-R.; Yao, X.-J.; Wu, W.-S.; Zhu, Y. Triterpenes and neolignans from the roots of Nannoglottis carpesioides. Phytochem. 2011, 72, 1804-1813. [CrossRef]

7. Huo, C.; Liang, H.; Zhao, Y.; Wang, B.; Zhang, Q. Neolignan glycosides from Symplocos caudata. Phytochem. 2008, 69, 788-795. [CrossRef] [PubMed]

8. Hillerns, P.I.; Wink, M. Binding of Flavonoids from Sophora flavescens to the Rat Uterine Estrogen Receptor. Planta Medica 2005, 71, 1065-1068. [CrossRef] [PubMed]

9. Liu, H.-X.; Lin, W.-H.; Wang, X.-L.; Yang, J.-S. Flavonoids from preparation of traditional Chinese medicines named Sini-Tang. J. Asian Nat. Prod. Res. 2005, 7, 139-143. [CrossRef] [PubMed]

10. Chen, W.; Tang, S.; Qin, N.; Zhai, H.; Duan, H. Antioxidant constituents from Smilax riparia. China J. Chin. Mater. Medica 2012, 37, 806-810.

11. Lima, T.C.; Ferreira, A.R.; Silva, D.F.; Lima, E.O.; de Sousa, D.P. Antifungal activity of cinnamic acid and benzoic acid esters against Candida albicans strains. Nat. Prod. Res. 2018, 32, 572-575.

12. Hu, K.; Kobayashi, H.; Dong, A.; Iwasaki, S.; Yao, X. Antifungal, Antimitotic and Anti-HIV-1 Agents from the Roots of Wikstroemia indica. Planta Med. 2000, 66, 564-567. [CrossRef] [PubMed]

13. Wang, D.; Yu, B.; Chen, C.; Duan, J.; Di, D.; Xiong, X.; Yang, Y.; Gao, H. New natural barrigenol-like triterpenoid isolated from the husks of Xanthoceras sorbifolia Bunge. Nat. Prod. Res. 2018, 32, 997-1003. [CrossRef] [PubMed]

14. Zhou, Y.J.; Guo, Y.J.; Yang, X.L.; Ou, Z.L. Anti-Cervical Cancer Role of Matrine, Oxymatrine and Sophora Flavescens Alkaloid Gels and its Mechanism. J. Cancer 2018, 9, 1357-1364. [CrossRef]

15. Wang, A.H.; Gao, X.X.; Huo, X.K.; Huang, S.S.; Feng, L.; Sun, C.P.; Zhang, B.J.; Ma, X.C.; Jia, J.M.; Wang, C. Antioxidant acetophenone glycosides from the roots of Euphorbia ebracteolata Hayata. Nat. Prod. Res. 2018, 32, 2187-2192. [CrossRef]

Sample Availability: Samples of the compounds 1, 2, 3 and 6 are available from the authors. Especially, compound 6 , as a major component, can be got a lot.

(C) 2020 by the authors. Licensee MDPI, Basel, Switzerland. This article is an open access article distributed under the terms and conditions of the Creative Commons Attribution (CC BY) license (http://creativecommons.org/licenses/by/4.0/). 